ORIGINAL ARTICLE

\title{
Some body wants to be normal: an account of an HIV narrative
}

\section{A Mooney}

J Med Ethics; Medical Humanities 2005;31:72-80. doi: 10.1136/jmh.2005.000198

Narrative accounts of illness often focus on the sociological construction of illness and neglect the body. This paper explores themes of seeing and being seen in the narrative of an HIV positive man to show the importance of uncovering the psychological and corporeal experience of HIV. Such accounts complement and enhance conventional medical accounts of illness. Poignantly, it is a story of how he understands others as reading his body and writing on it. Further, his story is not one that is in circulation. Accounts of positive heterosexual males are few. This paper seeks to add at least one account to the public record so that others may have narrative resources to draw upon. Narrative analysis provides new perspectives on the lived experience of HIV, which are crucial to appreciate how it might be possible to live a positive life.

Correspondence to: A Mooney, Centre for Language Communication Research, Cardiff University, Humanities Building, Colum Drive, Cardiff CF10 3EU, UK; mooneya@cf.ac.uk

Received 10 May 2004 Accepted for publication 4 January 2005 - 1 or us, the human body defines, by of distribution of disease: a space whose down, in accordance with a now familiar geometry, by the anatomical atlas ${ }^{\prime \prime}{ }^{.}{ }^{1}$

What happens to my body happens to my life. $^{2}$

So much recent scholarship has focused, rightly, on the social construction of illness that we may be in danger of forgetting that illness is in the body. Bodies carry things that are illnesses. Some of these things are themselves bodies in another sense-viruses, bacteria. Sometimes our bodies are at disease. Something is not working the way it is supposed to be. ${ }^{3}$ Further, constructions of illness are written on the body.

"Our bodies describe the story of our lives for better or for worse". ${ }^{4}$ Sometimes, the body has to be spoken for. Its story is not always legiblethat is, clear and transparent. A common way of telling the story of the body is in the form of medical and biological language. Such a story might better be called a description or an explanation. In terms of allopathic medicine, it is clear that science is just another way of telling a story and then acting on the basis of this. The notion that science is objective, true, and singular has long been under attack..$^{5-9}$ Science is, however, still the primary framing device for illness, even though other perspectives are increasingly included. Historically speaking, the lines, volumes, surfaces, and routes are laid scientific framing of human immunodeficiency virus (HIV) was dependent on more individual narratives. In particular relation to the early days of HIV, Patton notes:

In the first few years of the epidemic...Many men (and some women) willingly gave evidence of their illness and of their life, describing symptoms and answering long epidemiological questionnaires about the intimate details of rich and complex sex lives... But once the disease had been wrested out of the discourse of people living with AIDS, once HIV was discovered and could be made to perform in the laboratory without homosexual bodies, science no longer wanted to hear that discourse. ${ }^{10}$

Before scientific theory comes the story. When the scientific theory is able to explain and predict, individual narratives are no longer required as a starting point. They become merely exemplars of the theory that they informed.

\section{JOHN'S STORY}

This paper examines a body carrying the HIV and the resulting narratives. It is a particular case: one person who regards his body as the carrier for more than just an illness. For reasons of confidentiality, I will call this person John. John does not consider himself normal, and adjusts his body to the very normality from which he is alienated. It is not the qualified gaze that John fears, ${ }^{1}$ but, rather, the way in which people may alter their gaze once they know what they cannot even see. What is feared is the way in which others will write his illness on his body. Although this is certainly a social construction, it finds expression physically in an active dissembling of a bodily state. Treichler finds "Turner's postulates" useful in "rewriting the AIDS text"11: "( 1 ) disease is a language; (2) the body is a representation; and (3) medicine is a political practice" ${ }^{\prime 2}$

The gaze John fears is the one he has constructed and apprehends. Lacan writes of "the pre-existence of a gaze-I see only from one point, but in my existence I am looked at from all sides...We are beings who are looked at, in the

Abbreviations: GUM, genitorurinary medicine; HIV, human immunodeficiency virus; IVDU, intravenous drug user; STI, sexually transmitted infection

it would like to thank Andrew Edgar for discussions, which prompted new ways of thinking about this data. 
spectacle of the world". ${ }^{13}$ In short, John sees himself being seen. This is neither an epiphany nor an actual event. Simply, he already sees himself as he fears others would see him. As his body carries HIV he cannot see his body as normal. As a consequence, he cannot see himself as normal.

The narrative examined in this paper is also an explanation, one in which the body is central. The HIV body cannot speak for itself unless one has access to bodily fluids and scientific measures. The story that the narrator, John, tells, the subject of this paper, is very different from a medical account of HIV and AIDS.

HIV is in fact written on the body at the level of DNA through RNA transcription. ${ }^{\text {ii }}$

Joughin notes that HIV is "a retrovirus which works its wiles in reverse transcriptions, breaks codes, and en(s)crypts itself within a body/text which can no longer distinguish inside from outside" (my emphasis). ${ }^{15}$ The AIDS discourse is itself an epidemic. Joughin reminds us that:

Just as AIDS is a writerly sickness writ large, an epidemic of, and in, signification, the skewed parameters and loaded positionalities of its reinscription function within a complex discursive field in which many reactional and entrenched narratives already intersect. In short, we need to remember that the signifier "AIDS" is wielded as much in silent domination as in signification (Joughin, ${ }^{15} \mathrm{p}$ 147).

HIV, however, is not, perhaps, the usual sort of illness. ${ }^{16}$ In the case of HIV (until AIDS or opportunistic infections), there is no visible sickness as such. Herzlich affirms a relationship between illness and effect such that: "The individual evaluates his condition not according to its intrinsic manifestations, but according to its effects" ${ }^{17}$ HIV is not a serious illness in the asymptomatic person in terms of "intrinsic manifestations". In terms of "effects", however, the story is quite different. HIV is more appropriately a "condition". It is a condition that influences the way of telling and living the body, which includes relations with others (Herzlich, ${ }^{17}$ p 81).

\section{BACKGROUND}

The research background to this paper is important in both a general and particular way. Over the past three years I have interviewed and spoken to dozens of positive people and professionals working in advocacy, care, and support organisations. One thing is clear: every positive experience is different. Naturally there are some points of intersection in terms of difficulties with-for example, opportunistic infections and drug regimes, and family and relationships. Just when I thought I had heard it all, however, I would be surprised.

I am not suggesting that nothing at all can be said about HIV in general. Rather, in this instance, I want to focus on an individual and (among my respondents) unique interpretation of the self as positive. The individual in this case draws largely on public narratives from the mass media of the mid 1980s. Now, they would be considered stereotypes. These representations of HIV have, however, been internalised by John, although at the same time being attributed to a generalised other. Whether this is because his diagnosis

iiFor a provirus to produce new viruses, RNA copies must be made that can be read by the host cell's protein making machinery. These copies are called messenger RNA (mRNA), and production of mRNA is called transcription, a process that involves the host cell's own enzymes. Viral genes in concert with the cellular machinery control this process: the tat gene-for example, encodes a protein that accelerates transcription. Genomic RNA is also transcribed for later incorporation in the budding virion. ${ }^{14}$ occurred in that period or because he accepts these narratives as true is beside the point (though I would opt for the latter). He can be understood as being trapped in a now dated system of signification. It is one that he has internalised to such an extent that it influences not only his thinking, and his ways of talking about HIV and himself, but also the way he sees his body. Thus although cultural constructions of HIV have moved on considerably, John has not.

John's experience, as particular as it may be, tells us something about positive lives generally, but in some ways it is very basic. To communicate with other people, an individual has to use a form that will be understood. although illness can be a very private experience, language that speaks about it has to be shared. What John's view of HIV shows clearly is that one often has to draw on existing resources. Certainly this offers some choices. Further, although it is possible to forge some new ways of speaking and writing, this will usually take the discourses already circulating as a necessary departure point.

This interview took place as part of a broader investigation into HIV and quality of life. Respondents in the UK were recruited through some local HIV non-government organisations (NGOS), but by far the majority (including John) contacted me after I placed an advertisement on the web page of Positive Nation magazine. Some of these contacts decided they did not actually want to talk. John had made sure I was who I said I was (through some internet and telephone research) and was thus happy to meet with me, as he considered a researcher to be part of the HIV community. John and I initially met away from his home city. Because of the short time available on that occasion, and the failure of recording equipment, we decided to meet again at his house for a whole day. From this, 220 minutes of recorded and transcribed data is used here. ${ }^{\mathrm{iii}}$

Other matters we discussed will be mentioned, though it will be made clear that these are derived from field notes. The interview was semistructured, covering a number of topics: medication, stigma, relationships, HIV support groups, confidentiality, and work. This kind of narrative is not yet routinely circulating $^{18}$ as it is from a heterosexual positive man in the UK. I quote John at length in an attempt to give voice to his story. Although this is not enough of a reason, it is certainly an important part of work with positive people. The respondents I have spoken to, especially those not involved in the gay community, often remark that there are no representations of "normal" positive people-that is, people like them.

This particular interaction was unsettling. Even before the extended session I had non-specific reservations about whether I should go. Something about John made me uncomfortable. In retrospect, it is more than likely that he felt the same. To talk to a stranger about the most intimate aspects of one's life and about a condition that you associate with dirt and contagion cannot be easy. Our conversation often became very heated. I repeatedly tried to challenge his vision of himself. I would point out alternative readings and realities that he could enter into. Despite this frustration, I was finally impressed with John's honesty and integrity. For him, there were no alternate readings. The one he had internalised was true. This encounter (as many others in the course of this research) made clear the limits of my understanding. If and until HIV happens to my body, it is impossible to say how I would read it.

\section{FRAMEWORK AND STRUCTURE}

The structure of this paper attempts to mirror the structure of John's extended narrative. In one way, his story can be

iiipauses are marked by (.) and line numbers of the original transcript are given: I indicates a single line, II indicates more than one line. 
understood as being structured like a typical claim/denial. ${ }^{19}$ The claim is that HIV does not carry stigma, John's denial is that it does. This denial is structured along thematic lines. The themes are realised as episodes in the text.

It is worth being clear about what I mean when I describe a text as "episodic". Van Dijk and Kintsch, after suggesting examples of topic change markers, summarise:

\section{The general strategy, thus, is that if some sentence no longer can be subsumed under a current macroproposi- tion, a new macroproposition will be set up, of which the change markers are the respective partial expressions. ${ }^{20}$}

I suggest that to better understand the notion of a "macroproposition" we understand them as "themes", related to an overarching "subject". I intend "theme" and "subject" in this understanding to be drawn from musical rather than from linguistic terminology. Understanding episodic texts in terms of subject and themes accounts for the way in which episodes can recur, or be interrupted or suspended or self contained.

We can understand the overall purpose of the text as the "subject" and the premises that support it as "themes" subordinate to, drawn from, or based on the "subject". Thus, while the individual themes may or may not be related to each other, they all articulate an aspect of the subject or support it in some way. An episodic text, then, can be defined as a text that is a series of articulated and developed themes united by a subject.

The subject captures the point of the text. Unlike a subject in musical compositions, however, it may or may not be articulated explicitly. The themes are derived from material in the subject, as they are in music. The episodes of a fugue-for example, "are nearly always based upon figures in the Subject or Counter-Subject [answer to the Subject], and...often consist of a sequential treatment of such figures". ${ }^{21}$ Further, the subject interaction can also be related to the notion that argument is dialogic counter-subject interaction. If we understand macropropositions in musical terms, it is easier to understand how episodes can recur, be interrupted, and so on. Musical themes can appear, disappear, undergo transposition, inversion, repetition, and various other formal manipulations and substantive embellishments. Thus "the coherence of the whole is created solely by the unity of a few things (and motifs), which are developed in variations" in addition to their relationship to the subject. ${ }^{22}$

The analysis of this interview starts from the structure of John's narratives and explores the themes that achieve this. A structural analysis of this interview shows alternation between five themes. I deal with them in the order that they first occurred in the narrative. After these initial entries, John moves back and forth among the themes. Regardless of questions I asked, all accounts were clear instantiations of one the themes.

John starts talking about the artefacts of HIV (medicine and literature) and how he hides them. In the first section, I deal with this in terms of how John understands himself as being seen by others. Essentially, these episodes deal with how he "covers" (in Goffman's terms) the stigma of being positive. He then moves on to talking about how positive people are represented, and what he is "supposed" to look like. This is discussed in the second section. The third theme deals with stigma, including who John can disclose to (his "own" or the "wise") and why he cannot disclose to the "other". The fourth theme is directly related to the third. John is looking for a relationship, but he will only consider positive women. Finally, the fifth theme (which is implicit in the others, and can be understood as the "subject") examines what John understands as "normal". Although he works at passing for normal, he knows that he is not.

\section{HOW WOULD YOU KNOW HIM?}

I will begin by looking at the way other people might describe John as it is so strikingly different from the way he sees himself as a positive person. He is a professional, working in a large city. Apart from a severe period of AIDS related illness four years ago, and a period of unemployment following redundancy, he has been working continually since his diagnosis thirteen years ago. Herzlich finds that illness is often associated with inactivity and that "[b]eing off work is an institutionalized stopping of activity" (Herzlich, ${ }^{17}$ p 78). John often states how he has continued to work and any periods of not working are not (except in one case) directly related to illness. In fact, continuing work is central to John's negotiation of "normality". He travels often and socialises with friends and colleagues. John is healthy in that he shows no signs of illness. He is also fastidious that anything material connected with HIV is carefully hidden.

The first thing we talked about was medication. Usually the topic of medication in interviews with positive people revolves around the toxicity of the drugs, the side effects that make day to day living uncomfortable or impossible. Sometimes medication is the cause of apparent bodily changes, lipodystrophy-for example. John did not talk about any of these things. He talked about how he disposed of empty medication bottles and how to travel with HIV medication. Medication is important to consider because "up front it's the extent of" (1 2154) the effect of HIV on John's life. It is one of the few physical "symptoms" of his serostatus.

John showed me a bottle containing fifteen days of medication.

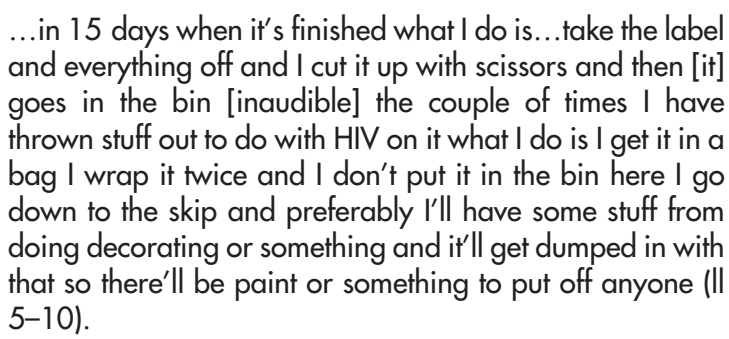

I queried whether anyone would look for something like that. He acknowledged that this was "sort of paranoia" (1 12 ). The routines he has assembled around anything with the letters HIV on it have, however, incorporated this "paranoia" into daily activities.

Strategies around medication also came into play when travelling. The medication is "disguised" (1 2156) in other packages so that it "looked innocent" (1 2157) with "all the identifying marks" (1 2166) taken off. It should be borne in mind that medications are unlikely to have "HIV" stamped on them. Further, to recognise a drug name as being a treatment for HIV requires specialist medical knowledge that only a positive person or someone involved in caring for them would have. Goffman notes that strategies like this, which attempt to control information around stigma might include "what espionage literature calls a "cover"". ${ }^{23}$ Indeed, the reference to spies is apropos as it occurs around other topics in the interview.

The discussion of medication indicates the importance of John presenting a non-HIV face to the world. Although HIV is written in his body (and his behaviour), it is not always a legible script. If it was clear that he was positive, there would be no point in engaging in the careful disposal and covering 
of medication. While the medication bottles are destroyed and camouflaged so that they cannot be found accidentally (or if one was actively looking) other material is hoarded.

most of the stuff that I've collected over the three years because it's only three years that I even discovered Positive Nation magazine existed so basically there's about three years supply of stuff and it sits up in the attic and it doesn't really get cleared out because there's all this palaver [laughter] about making sure that I wouldn't actually be found with it or no one would trace it back to me (II 1216).

(Positive Nation is the UK's HIV and sexual health magazine. It is published by the UKC: the UK Coalition of People Living with HIV and AIDS. ${ }^{24}$ ) The material is incriminating. This is clear not only from the strategies that John employs to dispose of or hide it, but also from the lexical choices he makes. He "disguises" the medication so it looks "innocent". The direct implication is that in its natural state it would "incriminate" him somehow. The notion that material could be "traced back" to him, that he could be "found with it", suggests again something illegal. This is the kind of discourse someone might use in relation to illegal drugs. The material here, however, is routine, legally procured and prescribed HIV medication, and Positive Nation magazines. The control of his medication can be understood as adherence to normality. The lengths that John goes to indicates the power of HIV as a negative identifier in his wider world.

\section{WHAT IS HE SUPPOSED TO LOOK LIKE?}

The stereotypical face of HIV for many people is still that of the "AIDS victim". I use the term here deliberately to highlight the way in which the mass media, particularly in the late 80 s and early 90s, portrayed HIV. John comments on the difficulty of orienting to HIV when all that is given is a "false" view of the illness.

... and the ones [positive people] who you know bloody Princess Diana goes and visits somewhere and lo and behold there's these mobile skeletons and they have about two months left to live and she holds the hand and makes front page news and you think well hang on I'm not looking like a skeleton yet (II 86-8).

The only positive people that many people have seen are those dying of AIDS rather than those living with HIV. ${ }^{25}$ John is certainly in the latter category, even though he, like many positive people, has been hospitalised with a CD4 count of zero, ${ }^{\text {iv }}$ AIDS related illnesses, and a bleak prognosis.

Further, the "yet" signals that he sees this state as inevitable. He says of this illness period "I can never work out quite how near to being dead I was" (ll 2217-8). Crimp's analysis in the early 90s finds that even the person dying of AIDS is not openly shown. "For the most part, though, they are not seen, or only partially seen, for these are portraits of the ashamed and dying". ${ }^{26}$ He goes on, "Most often they appear like terrorists, drug kingpins, and child molesters, in shadowy silhouette, backlit with light from their hospital room windows" (Crimp, ${ }^{26} \mathrm{p} \mathrm{119)}$ ). In such portraits, if they are less "ashamed" it is because they are "innocent" (Crimp, ${ }^{26} \mathrm{p}$ 120). "They are so innocent that they can even be shown

${ }^{i v} \mathrm{CD} 4$ count is a measure of immune system strength as it measures the level of Thelper cells in the blood. A CD 4 count of zero essentially means that the immune system is not functioning at all. being comforted, hugged, and played with" (Crimp, ${ }^{26}$ p 120). This has changed somewhat with the presentation of more heroic figures, such as Tom Hanks's character in the film Philadelphia, and the use of characters who happen to be positive, like the character Mark Fowler in the UK soap Eastenders.

It is important, however, to note the distinction between the representations that Crimp is dealing with and those in film and television. Crimp's work is commenting on people who are actually positive and how they are represented. Fictional characters are not necessarily bound by the same social and personal constraints as positive people. Conflict, discrimination, and acceptance can be scripted in a way that does not always match up with the experience of positive people.

When John starts talking about HIV and what it signifies, it becomes very clear why he takes such pains to dispose of medication bottles and why he talks about them as though they are incriminating evidence.

\section{STIGMA: OR WHAT HIV MEANS}

I will explain briefly how mapping related to the body and HIV's relation to the body and will elaborate further with examples from the transcript. For John, HIV is associated with sex, gayness, transgression, non-normality, death, contagion, and stigma. To "come out" as positive means that these meanings will be mapped onto his person, onto his body. They already are implicitly mapped in so far as this is his understanding of HIV. He quite clearly owns his "stigma"; essentially this means he has already written these negative meanings of HIV on his own person. It is only possible to be "out" about his status with those who are of his own "subculture". I use the term "subculture" because John uses it. This is not the subculture of style and behaviour, which marks a group out from hegemonic practice (though the status and power relations may be comparable). ${ }^{27}$ It is not so much about style as substance-that is, a close relationship with HIV in some way. Further, members of the subculture do not necessarily display their affiliation: infact it will often be hidden. John uses "subculture" to refer to his stigma community, those sympathetic others (Goffman, ${ }^{23} \mathrm{pp}$ 18ff). Sometimes the designation also extends to include the "wise", usually those working in the HIV world (nurses, doctors, staff at support groups, and so on).

John has no fear of being discredited in this subculture. Whether this is because they read his positive body differently, or because they have no privileged position of "normality" to judge him, is not clear: but whose words are written on his body? In part, they come from established myths about HIV; that you have to be homosexual, an intravenous (IV) drug user, or somehow deviant and immoral to get it. They also come from John's experience of the positive world; one that for many years was largely mediated and obtained from the mass media. I suggest this lack of alternate experiences makes resistant readings of negative representations extremely difficult. In turn this makes alternative narratives becoming public very difficult.

What does seem clear, however, is the physicality of the stigma. ${ }^{28}$ Goffman writes:

the Greeks, who were apparently strong on visual aids, originated the term stigma to refer to bodily signs designed to expose something unusual and bad about the moral status of the signifier. The signs were cut or burnt into the body and advertised that the bearer was a slave, a criminal, or a traitor-a blemished person, ritually polluted to be avoided, especially in public places (Goffman, ${ }^{23}$ p 11). 
Goffman notes that the root of stigma is usually detectable. One might miss, or cover the implications of the stigma, or even miss or cover the stigma itself, but it is primarily rooted in the physical. HIV is not, however, written on the body in a legible way. Unless one has access to blood and ELISA tests and the like, the HIV is invisible, but the experience of stigma is physical. Because John wants his "actual social identity" to be constantly hidden among normals (that is, he wants to pass as normal) he is always discreditable (Goffman, ${ }^{23} \mathrm{p} 4$ ).

Thus the "real" body is kept to the positive world; positive status is only disclosed to others of positive status and those in the field. He can only talk about this "real" body in a limited space. Body as origin of projection of self in the world can be manipulated such that one appears to be "normal". One is not, however, "normal" because one is positive. I hasten to add that this is not my view. I am only trying to map, and make sense of, what John related to me. He was adamant that I could not understand what it was like to be positive and refused my attempts to "normalise" or perhaps "randomise" the fact that he is positive (in that I argued it could happen to anyone). It is also important to note that John reproduces readings of HIV that were in circulation in the late $80 \mathrm{~s}$ when he was diagnosed. It seems to me that the point of his diagnosis and the isolation he experienced for the next eight years (during which time he disclosed to no one and did not even meet another positive person) are central to his own lexicon of HIV.

The stigma is difficult to unpack logically. Certainly some of it has to do with the association of HIV with homosexuals. This came up more than once (in fact a dozen times) in the interview, especially in relation to the effects of disclosure. In the following, we also see the association of Black Africans with HIV.

\section{R: You never considered telling your family? \\ $\mathrm{J}$ : No no no chance it's just that on the list of people to tell your family would be the lowest on the list you were gonna tell one one one of the reasons was and still is to a certain extent was that the family might think you're gay and I mean I I I mean that's still an issue now but it was certainly a big issue back when it was a gay plague I mean now it's not quite so bad because there's a lot more heteros who are positive and and a lot more black and no one's gonna think of you're black because I'm not but being gay is nothing to do with the colour of your skin so again from a hetero guy's point of view it's like [inaudible] if you're down the pub or whatever and you want to insult someone you call them a poof and particularly in the early 90 s it was because there weren't that many black Africans coming to the UK with it it was very much a it was gay plague. And the last thing on earth on top of all the other insults would be people thinking I was gay $\mathrm{R}$ : and especially your family thinking you were gay J: Precisely (II 122-135).}

( $\mathrm{R}$ refers to myself; $\mathrm{J}$ to John.)

"The perceived melding of AIDS and homosexuality results in the two concepts being stored together in the same cognitive schema in an individual's mind...Regardless of whether homosexual individuals have contracted AIDS (sic), homosexuality is associated with AIDS and vice versa". ${ }^{29}$ There appear to be a limited number of readings of positive status. In fact here, we are presented with what John sees as the two options. First, HIV means one is black. He notes that this is impossible. There is no way this could be written on or read from his white body. The second option, however, gayness, could be because "being gay is nothing to do with the colour of your skin". Being HIV positive might signify gayness. He goes on to say that he does not "know which would be worse, telling them [his parents] I was positive or telling them I was gay" (1l 140-1). For John, the two seem to be synonymous in terms of negativity if nothing else.

Disclosing HIV status has been likened to coming out as homosexual..$^{30}$ Although there is a parallel in the sense that coming out as either gay or positive places one in a minority, it is difficult to extend the analogy. Certainly there are some people who regard homosexuality as an illness. At least in the West, however, being gay is most often understood as innate. Being gay is not a health state and certainly not a terminal illness. It seems to me that the issues of mortality and stigma that HIV currently evoke, as well as placing one in yet another minority, mean that comparing the two occasions of disclosure can only go so far. That is not to say that HIV disclosure does not resemble "coming out" as gay in some social settings, especially in the past when scripts for such moments were not in circulation, legal sanctions were in place, and gay communities were not as out as they are now.

John's reluctance to disclose his HIV status for fear of being labelled gay might also be read by some as repression of his own homosexuality. Having spent so much time with him I find this difficult to accept. Although John would certainly be considered "homophobic" by many, his unwillingness to be associated with homosexuality is more about him wanting to be "normal". I am reluctant to provide great detail about John's upbringing. Perhaps it is enough to say that he comes from a very religious family that has high social standing and visibility in its community. Further, the part of the country in which he grew up is not one in which deviations from masculine norms of any sort are easily accepted. The culture in which John grew up was one that, "if you're down the pub or whatever and you want to insult someone you call them a poof".

The concept of the "gay plague" is an old one. The residue of discourse past is still present and active. Treichler writes: "Whatever else it may be, AIDS is a story, or multiple stories, read to a surprising extent from a text that does not exist: the body of the male homosexual. It is a text people so wantneed-to read that they have gone so far as to write it themselves" (Treichler ${ }^{11}$ p 42). It is clear that homosexuals and intravenous drug users are not considered to be normal in John's view. Whether homosexuals or intravenous drug users (IVDU) are positive or not is immaterial—for John they are not "normal" people whatever their status. Certainly he does not consider himself normal, his positive status precludes this. However, he carefully segments different kinds of non-normality.

His own "story" about how he became positive is credible, he argues, and does not relate to homosexuality.

\section{I have travelled a lot and I've been out to [other country] several times the story does stand up well actually it was getting up to no good in [other country] you know so the there it's a risk at all, the icing on the cake of disaster is telling them you've got HIV and the suspicion must be gay must be bisexual whatever I mean it's just not on (II 144- 8).}

While the story "does stand up", John's understanding of disclosure is that an immediate mapping of gayness or bisexuality would occur and that is "just not on". If John is right about the implications of being positive (one must be black, an IVDU, homosexual or bisexual) there is no reason why this should not happen, as homosexuality is not visible. The credible story of John's infection is not one he wants to tell normal people. 
What develops in this train of conversation with John is that stigma comes also from the communicability and incurability of HIV. John sees the fact that the primary mode of transmission is sexual as the root of the stigma.

I think the only time I'd ever actually tell anyone in fact I'd probably write a book about the whole happy saga, is if they found a cure. Because when it no longer affects anyone else it will cease to be a a a source of of ah stigma (II 153-5).

The big problem with HIV and AIDS as a as an issue is the fact you can pass it on and not only can you pass it on you can you pass it on primarily through sexual contact and that that's why you know if you're wondering why it's a big bloody issue that's why (II 159-61).

Sexually transmitted diseases, even if curable, "are regarded as not the best diseases to have" (1 173). He cites the stricter confidentiality of genitourinary medicine clinics (GUM clinics) as a warrant for this. He then draws a parallel between disclosing any other sexually transmitted infection (STI) to family or friends with his decision not to disclose his HIV status.

I mean if I had gonorrhoea would I tell my parents well don't be bloody stupid it's the last thing you're gonna tell your parents so when so I think I've got HIV which is a sexually transmitted disease or you're gay or I'm an injecting drug user well [snort] you know who's the last people you tell well that's your parents and the standard that telling your family is taken to be a good idea with HIV if I had gonorrhoea it wouldn't be a good idea so why is it a good idea with the HIV (II 175-80)?

Again, the sexual transmission is only part of the problem. The suspicion of homosexuality and drug use figure again here. Other STIs are not equivalent to HIV. Historically speaking, Clark notes that these were "in the Victorian age regarded as "venial", or forgivable, sins of passion". ${ }^{31}$ HIV is not; it is a sin of deviance.

That John is not gay does not preclude his feeling like a "plague dog" (1 1668). In some untaped remarks he told me that disclosing his HIV status was tantamount to saying one was a paedophile. He refers several times in the taped interview to an exchange he had with another heterosexual positive man.

he said he felt dirty and I felt that was probably the best description of what it's like to have it. and and and it's always stuck with me he said I feel dirty ever since I had that diagnosis and again the weird thing about it is I feel the same but no one else can see that I feel dirty you know you know I haven't changed colour my hair hasn't fallen out nothing's changed visually but yeah I mean it's just that carrying this thing around that you the other problem is you don't want to give it to anyone else (.) and that becomes really restricting (II 208-13).

Here the physical and mental aspects of (self)stigma are captured by feeling "dirty" and result in "restriction" from "carrying this thing around". This captures the sense of contamination, uncleanliness, and moral transgression. Explicitly stating that nothing has "changed visually" signals that the feeling is nevertheless visceral; that one might have expected physical changes. Clearly he feels polluted. ${ }^{32}$
Certainly, following Douglas, he is also in an anomalous position in that he is trying to be "normal" and yet constantly aware of the fact that he is not. John does not fit into the categories that he is willing to recognise in society.

He says almost the same thing later in the interview, stating again that there have been no physical changes that are visible. Here, he acknowledges the "irrationality" of his feeling dirty.

it is summed up I feel dirty (.) I feel and again it's kind of because I don't look any different because I don't look like I've got HIV I don't look like a victim or anything I don't act like a victim (.) there's this weird thing that I I carry it and it's my it's my stigma it's not your stigma or anyone else's it's mine and that that's probably the worst thing and you know people who I've said that to before say well why don't you get rid of it (.) for me the whole AIDS thing would collapse like a pack of cards the moment we get a cure (.) when there's a cure you know I will cease to be a danger to anyone else and even anyone else who did get it for whatever reason (.) there wouldn't be an issue cause you'd take a few antibiotics and a magic treatment potion whatever (II 1612-21).

It is apparent here too that the dirt is contagious. ${ }^{\mathrm{V}}$

\section{WHO DO YOU LOVE?}

The body...has become... a text to be read, written or rewritten by "body-experts", be they doctors, beauticians, sports instructors or lovers. ${ }^{33}$

For most positive people relationships highlight the difficulties of living with HIV. In fact, it would be fair to say that in this interview (and many others) close to half the time (if not more) is spent talking about the difficulties of initiating or conducting relationships. The problem with relationships is that because of transmission, and perhaps also because of disclosure, John only considers positive women. This certainly removes some of the problem of when to disclose in a new relationship (Goffman, ${ }^{23} \mathrm{p} \mathrm{108).} \mathrm{In} \mathrm{the} \mathrm{following,}$ however, the possibility of transmission and stigma in general are backgrounded. The reasons why John does not feel like he could have relationships with negative females is not raised as such. They are presupposed here.

because if you felt you could have relationships with negative females then relationships wouldn't be an issue relationships are an issue because of the whole actual number of people who can have a relationship is measurable in the few hundreds (II 1484-7).

The scarcity of women is a concern as it minimises "chances".

see the big deal for for for for me and anyone who's positive is that chances like this don't come up every week...for me it's a case of, if I don't get on with this girl...when's the next one I'm gonna meet (II 1024-30)?

John contrasts this with the case of an "average guy" who would have a far easier time of it. The requirements for John

"Dirty" is also exactly the term John uses when talking about homosexuals; "they're [homosexuals] dirty buggers" (I 167), "you don't want those dirty buggers near us" (I 171). 
are more difficult. Not only does a potential partner have to be positive, she has to be "carrying on as normal as well" (l 1022). I will return to this concept of "normality" presently. It is worth noting, however, how John sees confidentiality as working against some of the interests of positive people. In a way, the confidentiality maintained in a GUM clinic is extended to most of the HIV sector involving positive people. Essentially it means that sometimes trying to live in the HIV world is like living in a GUM clinic in terms of confidentiality. While this makes the space safe, it is still a restricted space. This means that trying to meet potential partners in the HIV world is not always straightforward.

I mean I can't remember what film it was it was Platoon or something like that, the first casualty of war is the truth, well I sort of think with HIV, the first casualty of HIV is your friendships and relationships because everyone has the same reaction and they all start drawing back [pause] (II 213-16).

None of John's friends know that he is positive, so this "drawing back" cannot be directly experiential. In relationships, because of physical and emotional intimacy, HIV has to be negotiated in some way. Only considering positive women is part of this negotiation. It removes the possibility of being discredited, as the other person is in the same situation. The "drawing back" that John talks about echoes in its physical and emotional dimensions his feeling of dirtiness and consequent isolation.

This particular discussion about relationships brought to mind Winterson's novel, Written on the Body. Appropriately for discussion here, the narrator's lover has cancer. It has not manifested symptoms. The narrator (whose gender is never revealed) searches for information about bodies with cancer in order to understand the lover she has already abandoned (to the lover's husband's care-a research oncologist). At the start of the novel, the narrator muses: "Why is it that the most unoriginal thing we can say to one another is still the thing we long to hear? 'I love you' is always a quotation". ${ }^{34}$

John only reveals his real body to positive women; it is only here that he can hope to say and hear "I love you". The writing on his body, his feelings of contagion and dirtiness, can perhaps only be read by positive women if there is to be a chance to hear the three word quotation.

Written on the body is a secret code only visible in certain lights; the accumulations of a lifetime gather there...I like to keep my body rolled up away from prying eyes. Never unfold too much, tell the whole story (Winterson, ${ }^{34} \mathrm{p}$ 92).

The body can only be unrolled in the presence of someone who can stay still while hearing the whole story. Someone who will not draw back. ${ }^{29}$

\section{TALKING AND BODIES}

Talking itself is an embodied act. Gwyn writes: "voice is the explicit manifestation of the embodied nature of illness" (Gwyn, ${ }^{4}$ p 212). In terms of "hidden-ness" it is pertinent that John did not speak to anyone (except physicians; and even then only after an acute period of illness in year eight, before this there was no treatment at all) about his HIV for eleven years.

partly it was frustrating not being able to talk about it but one of the reasons I couldn't talk about it I mean I knew there must be other heterosexuals in the UK with it uhm but I couldn't couldn't work out who the hell are they and it's almost like you're a spy and you're in the KGB and you're in the UK but you don't know who the other bloody KGB agents are (II 80-3).

This association with spies and espionage has already briefly been mentioned. It is perhaps not surprising that Treichler, following Haraway, also finds these metaphors in scientific accounts of modern immunology (Treichler, ${ }^{11}$ p 59).

This silence is impossible to interpret in some ways. It is only when John started to speak about being positive (though in a limited context) that the silence became at all visible. In relation to communicative silence, which is visible, Sobkowiak writes:

Silence must be ranked as the overall least formally complex communicative entity. Indeed, except for size (duration), it has no formal exponents: no segments, no morphemes, no words to go by, just nothing (hesitation markers and audible breath-taking do not code CS [communicative silence], of course). By this token, then, CS should be regarded as (formally) unmarked compared to speech. Similarly, although nobody would deny that CS carries content, it would probably be agreed that in terms of content complexity CS is indeed unmarked relative to speech. ${ }^{35}$

In fact, the limited sphere in which John discloses, and the nature of this space in terms of confidentiality, means that silence is maintained. His silence, when uncovered, does express the negative features that Jensen associates with silence: separation, wounding, concealment and censorship, and dissent/disfavour. Jensen identifies one more feature, inactivity. ${ }^{36}$ The positive corollary of this is work and thoughtfulness, which captures the activities that John pursues in his effort to be seen as normal. He does not want his silence to be noticed or interpreted. John's silence is not intended or constructed to be communicative.

One can also read John's silence and "frustration" in a very physical and sexual way. Although John could not talk about it because he could not identify someone else appropriate to talk about it to, he felt he could not engage in any kind of dating or relationship activity. In fact, his first "relationship" mainly consisted in talking through his eleven years of silence. This woman "had this download of all my frustrations of 11 years of being positive and all the rest of it" (ll 660-1). Talking about being positive is a physical release. John likens the burden of not talking about HIV to being in a pressure cooker.

\section{WHAT IS NORMAL?}

Returning to the start in as far as returning to the body, appearances, and deception, I now try and map John's disjuncture between the normal and the non-normal. Normal people do not have HIV. What is more, normal people do not get HIV.

I don't understand that thing anyone could have got it whatever (.) if I hadn't gone shagging in [other country] I wouldn't have it end of debate but you know gay guys, if you weren't gay you wouldn't have it, drug users if you weren't in sticking bloody needles in your self you wouldn' $t$ have it (.) Normal people how would I define normal, people who happily married and are faithful don't do drugs and all the rest of it they don't get HIV (.) you know so one of the reasons I'm not too happy about the whole thing is that I I would have liked to be in the normal group 
but I know I'm not and I know I'm not because of my behaviour (II 1458-65).

John "would have liked to be in the normal group" but he is not. As alluded to, his understanding of what "normal people" think of HIV is taken from discourses around HIV at the time of diagnosis, and also from his own stance before his diagnosis. The experience of not being normal is the root of stigma, as Goffman notes (Goffman, ${ }^{23}$ p 17):

I mean one of the oddities of having HIV is that if I was negative I'd be the first person to say ship them off to a desert island and leave them to bloody rot (II 1453-4).

While John has to be said at one level to author his own stigma, it is very clear that he feels there is no other option. By this I mean it seems clear that he hears other voices writing the script of HIV; but the voices of the other are also his voice. Indeed, his congruence is remarkable.

Using an inclusive pronoun he says:

We'll never be bloody open minded about it and least of all because the people who have got it don't feel open minded about it (II 1605-7).

The first "we" refers to "the general population". John includes himself in this "we" as well as in "the people who have got it". This is a vicious circle. When one is in the (nonnormal) subgroup of positive people, though projecting an image of normality, the only representations that the normal group will see are AIDS victims. Positive people are invisible to "normal" people and to each other. Positive heterosexuals are particularly invisible; as John notes, it is like being "in the KGB...but you don't know who the other bloody KGB agents

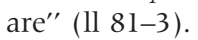

John's resistance to an alternative reading of his serostatus at this level and his alignment with the "general population" indicates the power of the narratives and myths that are still in circulation about HIV. The cultivation of a "normal" face can be theorised with respect to Foucault and his prioritising of the body as a site of "unique disciplinary power" (Gwyn, p 10). ${ }^{37}$

Normality is perhaps the central issue for John. Although he does not consider himself to be in the normal group, he acts as though he is. To begin with, he claims that it is not an act.

it was just kind of bizarre because it was having this one thing that you just couldn't talk to absolutely anyone at all about uhm and really I I think it was having to keep keep up the, cause it wasn't really a pretence because I did everything as normal anyway (II 77-9).

Although he was "doing" everything as normal anyway, things were not "being" normal. Otherwise there would be no "gulf", there would be nothing "bizarre", and there would not be "this one thing that you just couldn't talk" about. As noted, certain people are sought out for relationships because of similarities in this respect.

they're [white women] a bit like me because they tend to have this thing that everything's normal on the surface but below it's not normal and the bit that isn't normal is the fact that they find relationships difficult (II 259-61).

Again, yeah even though work wise and everything else it kinda looks normal (.) it never has been not at an emotional and personal level (II 2281-3).

The craving for normality is a desire to be in that normal group, subject to the same things as everyone else.

I spose the holy grail probably isn't the the the girlfriend in itself it's getting back to being normal I think that's where the cure becomes the critical thing because that means I'm as normal as anyone else (.) and yeah if that means I get run over by a bus and if I then get married get married and have kids get divorced that's bloody normal because everyone gets married and has kids and gets divorced that's what people do (.) and that means I'm back in normality and it's that it's the it's the feeling an outsider which is odd because no-one else knows (.) I mean you're one of the few peo- you know [friend] knows, people in GUM clinic knows and a few people in the support groups know and that's it (.) and again most of the people I've mentioned are in my subculture anyway (.) (II 2305-13).

This description of "normal" is eerily like a passage from an American government information pamphlet, America Responds to AIDS:

Married people who are uninfected, faithful and don't shoot drugs are not at risk. ${ }^{38}$

These are almost exactly John's own words in (ll 1458-65). People in the subculture include positive people, anyone involved in positive support groups, people involved in medical care, and those working in some other capacity in the field-for example, as researchers. These can perhaps be called collectively "wise", along Goffman's lines (Goffman, ${ }^{23}$ p 41). What is essential is that people in the subculture do not have a privileged position from which to read John's stigma; because they chose not to take one, or because they are positive. He spoke about this in relation to his position vis a vis other positive people.

and that's why when it comes to me going to support groups well frankly any poncey ideas that I'm better than anyone else (.) they definitely fall away cause actually (.) .... you get it yeah you get it as a result of your own behaviour and I got it from my behaviour it puts me in the same category as the rest of them [laughter] so tough shit (II 1465-70).

But generally, normal equals negative. When I queried John about "normal women" he responded:

well I tend to use normal and negative interchangeably (I 826).

The support groups provide a "back place" (Goffman, ${ }^{23}$ p 102) where disclosure is not required because presence implies positive status, but where issues surrounding HIV can be freely discussed.

Goffman argues that the stigmatised person is not completely accepted by "normals" and should not expect to be. S/he is part of "the wider group" but also different "and...it would be foolish to deny this difference" (Goffman, ${ }^{23} \mathrm{p}$ 147). The standards which define "normal" also define (in opposition) John's stigma. Ironically, if he did not so ardently wish to be in that normal group, one would 
expect his stigma to be less acute; he would not be subject (and subjecting himself) to that discourse. Another difficulty is that it is completely possible for John to pass as normal in most spheres of life. Yet he knows that he is an alien in a normal world. "The painfulness, then, of sudden stigmatization can come not from the individual's confusion about his identity, but from his knowing too well what he has become" and what he never can become (Goffman, ${ }^{23} \mathrm{p} \mathrm{158)}$ ).

\section{CONCLUSION}

Illnesses mean something. Even if the symptoms are not acute, indeed even if they are quiescent. My attempts to interrogate the meaning that John attributes to HIV did not lessen his stigma. It is possible he found my attempts even more alienating as our views were so incommensurable. Perhaps the problem is not what illnesses mean as much as what happens because of such meaning. The gaze that John apprehends as seeing him means that he works toward normality. His body, his silence, and his covering strategies are part of this work.

Despite hearing Sontag's call to reject metaphors of illness, ${ }^{39}$ Brody argues:

The major point is that "to give disease meaning" is not something we can choose to do or not to do. We are inevitably involved in the business of attributing meaning to illness whenever we tell stories about such people or even if we engage in merely medical diagnosis. ${ }^{40}$

Perhaps, however, what the two mean by "meaning" is not quite the same. Brody appears to be dealing with a more individualised meaning, whereas Sontag rejects the automatic, routine metaphors and stereotypes that attach to conditions.

Both are right. In the case of John, encouraging him to "see" or "understand" that his illness is not stigmatised completely ignores his own experience. It was also, at least for me, impossible. His primary desire is to be normal but for him this is impossible. He can, however, project normality while knowing all the while that this is subterfuge. His requirements are simple; to live as normal a life as possible. Although confidentiality, counselling, and antiretrovirals are all considered acceptable demands for positive people to make, John's experience at least shows us that some services (such as dating introductions) are not. More importantly, the only stories that John relates to and finds meaning in are those of other positive people exchanged personally. These stories are contraband. ${ }^{\mathrm{vi}}$

Either they are not circulated or they are detached completely from their speaker.

Narratives have the power to surprise us and, if we let them, they allow us to experience states that are not ours. Narratives are our way of communing with the other. They allow us access to and experience of our own bodies and illnesses and those of others. The tool of narrative shows things that blood tests and microscopes cannot. The human technology of narrative offers vistas and possibilities for action and interaction that differ from and complement the medical construction of the body.

viThough the Positive Speakers' initiative, active in many parts of the world, attempts to recuperate this.
Source of Support: The Language and Global Communication research programme of the Centre for Language and Communication Research has been funded for a five year period by the Leverhulme Trust.

\section{REFERENCES}

1 Foucault M. The birth of the clinic: an archaeology of medical perception [trans Sheridan AM]. London: Routledge, 1973:3.

2 Frank AW. At the will of the body: reflections on illness. Boston: Houghton Mifflin, 1991:13.

3 Crimp D. AIDS: cultural analysis/cultural activism. In: Crimp D, ed. AIDS: cultural analysis/cultural activism. Cambridge: October Books, 1988:3-16.

4 Gwyn R. Communicating health and illness. London: Sage, 2002:167.

5 Feyerabend P. Against method: outline of an anarchistic theory of knowledge. London: NLB, 1975.

6 Feyerabend P. Farewell to reason. London: Verso, 1987.

7 MacCormac ER. Metaphor and myth in science and religion. Durham, NC: Duke University Press, 1976.

8 Nash C. Narrative in culture: the use of storytelling in the sciences, philosophy and literature. London: Routledge, 1990.

9 Rorty R. Science as solidarity. In: Nelson JS, Allan M, McCloskey DN, eds. The rhetoric of the human sciences: language and argument in scholarship and public affairs. Wisconsin: University of Wisconsin Press, 1987:38-52.

10 Patton C. Inventing AIDS. New York: Routledge, 1990:130.

11 Treichler PA. AIDS, homophobia and biomedical discourse: an epidemic of signification. In: Crimp D ed. AIDS: cultural analysis/cultural activism. Cambridge: October Books, 1988, 31-70 at 64

12 Turner BA. The body and society. New York, Basil Blackwell, 1984: 209, 221.

13 Lacan J. The four fundamental concepts of psychoanalysis [trans Sheridan A]. New York: W W Norton, 1978, 72, 75.

14 http://www.aegis.com/pubs/Cdc_Fact_Sheets/1994/CDC94016.html (accessed 17 May 2005).

15 Joughin JJ. Whose crisis? AIDS/plague and the subject of history. In, Baker F, Hulme $P$, Iverson $M$, eds. Uses of history: Marxism, postmodernism and the Renaissance Manchester, Manchester University Press, 1991:140-152 at 146.

16 Navarre M. Fighting the victim label. In: Crimp D ed. AIDS: cultural analysis/ cultural activism. Cambridge: October Books, 1988:143-6.

17 Herzlich C. Health and illness: a social psychological analysis [trans Graham D]. London: Academic Press, 1973:84.

18 Couser GT. Recovering bodies: illness, disability and life writing. Wisconsin: University of Wisconsin Press, 1997.

19 Hoey M. Signalling in discourse: a functional analysis of a common discourse pattern in written and spoken English. In: Coulthard M, ed. Advances in written text analysis. London: Routledge, 1994:26-35.

20 Van Dijk TA, Kintsch W. Strategies of discourse comprehension. New York: Academic Press, 1983:204.

21 MacPherson S. Form in music. London: Joseph Williams, 1915:210.

22 Kundera M. The art of the novel. London: Faber and Faber, 1988:83.

23 Goffman E. Stigma: notes on the management of spoiled identity. Harmondsworth: Penguin, 1990:116.

24 www.positivenation.co.uk (accessed 17 May 2005).

25 Crystal S, Jackson M. Health care and the social construction of AIDS: the impact of disease definitions. In: Huber J, Schneider BE, eds. The social context of AIDS. London: Sage, 1992, 163-80 at 164.

26 Crimp D. Portraits of people with AIDS. In: Grossberg L, Nelson C, Treichler P, eds. Cultural studies. London: Routledge, 1992, 117-133 at 119.

27 Hebdige D. Subculture: the meaning of style. London: Methuen, 1979.

28 Brandt AM. AIDS: from social history to social policy. In: Fee E, Fox DM, eds. AIDS: the burdens of history. Berkeley: University of California Press, 1988, $147-71$ at 156.

29 Le Poire BA, Hiroshi O, Hajek C. Self disclosure responses to stigmatizing disclosures: communicating with gays and potentially HIV+ individuals. Journal of Language and Social Psychology 1997;16:159-190 at 160.

30 D'Cruz P. In sickness and in health. Calcutta: Stree, 2003:8.

31 Clark KA. Pink water: the archetype of blood and the pool of infinite contagion. In: Elwood WN ed. Power in the blood:a handbook on AIDS. Politics and communication. London: Lawrence Erlbaum, 1999, 9-24 at 13

32 Douglas M. Purity and danger. London: Routledge, 1966.

33 Fox N. Postmodernism, sociology and health. Buckingham: Open University Press, 1993:20.

34 Winterson J. Written on the body. London: Cape, 1992:9.

35 Sobkowiak W. Silence and markedness theory. In: Jaworski A, ed. Silence:interdisciplinary perspectives. Mouton de Gruyter, 1997:53.

36 Jaworski A. Aesthetic, communicative and political silences in Laurie Anderson's performance art. Silence:interdisciplinary perspectives. Mouton de Gruyter, 1997:26

37 Frank AW. The wounded storyteller. Chicago: University of Chicago Press, 1995.

38 WAUDAG (University of Washington Discourse Analysis Group). Resisting the public discourse of AIDS. Textual pract 1989;3:388-96 at 391.

39 Sontag S. Illness as metaphor and AIDS and its metaphors. Harmondsworth: Penguin, 1991.

40 Brody H. Stories of sickness. New Haven: Yale University Press, 1987:64. 